\title{
Institutional and farm-level challenges limiting the diffusion of new varieties from public and CGIAR centers: The case of wheat in Morocco
}

\author{
Yigezu A. Yigezu ${ }^{1}$ (D) Zewdie Bishaw ${ }^{2} \cdot$ Abdoul Aziz Niane $^{3} \cdot$ Jeffrey Alwang ${ }^{4} \cdot$ Tamer El-Shater $^{5}$. \\ Mohamed Boughlala ${ }^{6} \cdot$ Aden Aw-Hassan $^{3} \cdot$ Wuletaw Tadesse $^{7} \cdot$ Filippo M. Bassi $^{7} \cdot$ Ahmed Amri $^{7} \cdot$ Michael Baum $^{7}$
}

Received: 2 September 2020 / Accepted: 21 June 2021 / Published online: 6 July 2021

(C) The Author(s) 2021

\begin{abstract}
Low adoption of agricultural technologies slows efforts to increase agricultural productivity and enhance rural livelihoods in developing countries. A large body of literature has sought explanations for the problem, but the focus has been mainly on microlevel farm and community factors affecting adoption. Institutional factors such as policies and market conditions, which are also important, have been largely overlooked and, few, if any, studies combine the two levels of analysis. We use Morocco as a case study to analyze institutional and farm-level factors affecting diffusion and adoption of improved wheat varieties. Results show both sides to be important. Institutional factors such as overly stringent variety testing procedures, imbalance of power among actors in the seed sector and ill-conceived variety licensing contracts limit access to seeds of more recently released varieties. Adoption of older new varieties is found to be affected by farm and farmer characteristics, but imperfect access to new seeds, sometimes associated with the failings identified above, is also a constraint. Findings signal the need for increased private engagement in seed multiplication; revised variety testing procedures; alternative royalty mechanisms; and enhanced linkages between public research and private seed companies.
\end{abstract}

Keywords Variety development -Variety release and acquisition $\cdot$ Seed production and commercialization · Institutional factors · Demand-side factors $\cdot$ Wheat $\cdot$ Morocco

Yigezu A. Yigezu

y.yigezu@cgiar.org

Zewdie Bishaw

Z.Bishaw@cgiar.org

Abdoul Aziz Niane

a.niane@cgiari.org

Jeffrey Alwang

alwangj@vt.edu

Tamer El-Shater

tamer_149@hotmail.com

Mohamed Boughlala

boughlalamm@yahoo.fr

Aden Aw-Hassan

aawhassan@gmail.com

Wuletaw Tadesse

W.Tadesse@cgiar.org

Filippo M. Bassi

F.Bassi@cgiar.org
Ahmed Amri

A.Amri@cgiar.org

Michael Baum

M.BAUM@CGIAR.ORG

1 International Center for Agricultural Research in the Dry Areas (ICARDA), P.O. Box 11711, 2 Port Said, Victoria Sq, Ismail El-Shaaer Building, Maadi, Cairo, Egypt

2 International Center for Agricultural Research in the Dry Areas (ICARDA), Addis Ababa, Ethiopia

3 International Center for Agricultural Research in the Dry Areas (ICARDA), Beirut, Lebanon

4 Department of Agricultural Economics, Virginia Tech, Blacksburg, VA 24061, USA

5 International Center for Agricultural Research in the Dry Areas (ICARDA), Damascus, Syria

6 Meknes Agricultural Research Center, Institut National de la Recherche Agronomique (INRA), Meknes, Morocco

7 International Center for Agricultural Research in the Dry Areas (ICARDA), Rabat, Morocco 


\section{Introduction}

A large body of literature finds that agricultural research conducted by the Consultative Group for International Agricultural Research (CGIAR) and its national partners has contributed to improved livelihoods among the poor (Adato and Meinzen-Dick 2007; Thirtle et al., 2003). As budgets tighten, CGIAR and other research centers are under pressure to demonstrate that research investments are money well spent (Renkow and Byerlee, 2010). A main engine of livelihood improvements is increased productivity associated with new agricultural technologies. Several studies have documented that new crop varieties have made major contribution to yield increases (Bailey-Serres et al. 2019; Lantican et al., 2016; Evenson and Gollin 2003), but their diffusion in the developing world has been slow (Yigezu et al., 2019; Lantican et al., 2016; Walker, and Alwang, 2015).

Limited diffusion can result from combined effects of multiple institutional and farmer demand factors. Institutional factors include: Inadequate capacity to generate technologies; misalignment of breeding objectives with farmer preferences; problems with technology testing and release systems; disincentives for private-sector acquisition and licensing of new technologies; inefficient extension systems; and flaws in credit and input systems. Factors affecting farmer demand include: Incorrect perceptions or lack of knowledge; lack of finance and access to credit; risk aversion and other behavioral effects; and lack of alignment of farmer demand for variety attributes with the supply of attributes. In addition, heterogeneous agroecological conditions make some varieties appropriate in some areas, but not others.

The literature's focus on adoption determinants is partly due to the relative ease of conducting household surveys, to methodological biases pushing some researchers away from qualitative farm and institutional analysis, and to lack of a convincing framework to conceptualize institutional failures. As a result, these studies implicitly assume that the varieties being studied are suitable given farmer objectives and underlying conditions and that no institutional constraints affect information about and access to the technologies.

We consider both types of constraints and will show how ignoring one side can lead to erroneous conclusions. For example, if a study using a farmer survey finds inadequate access to seeds to be a constraint, it is fruitful to identify bottlenecks in seed distribution systems. If institutional factors are investigated, and adequate supply of certified seeds is verified, then a farm-level analysis of factors inhibiting demand should be conducted. Even in this case, institutional constraints such as incomplete area-specific testing might responsible; agro-ecological heterogeneity might mean that a variety well-suited to some areas may not be suited to others. Addressing only one side of the equation gives an incomplete picture.
Because of the long history of joint wheat breeding by public and CGIAR research centers, Morocco is used as a case study. The Morocco wheat sector is an especially interesting case because a partnership (INRA-CG) between the Moroccan Institut National de la Recherche Agronomique (INRA) and two CGIAR centers-the International Maize and Wheat Improvement Center (CIMMYT) and the International Center for Agricultural Research in the Dry Areas (ICARDA), had produced many widely diffused improved varieties in the 1980s and 1990s. After 1998, this pipeline dried up and few newer varieties are now seen in Morocco.

Two broad objectives are pursued. First, the paper addresses the question of why varietal release rates for INRACG germplasm dropped after 1998. Second, the paper explores why few of the INRA-CG varieties released after 1998 have been widely diffused, despite success in experimental trials. Institutional factors largely explain both outcomes, but we also find that farm-level and localized factors play a large role in constraining adoption of older improved varieties. Thus, both sides are important. This paper follows a combination of the integrated seed sector development framework (Munyi and De Jonge, 2015; Louwaars et al., 2013) and the agricultural innovation systems (AIS) framework (Hounkonnou et al., 2012; WB 2006; Hall et al., 2003) to examine the entire seed value chain from varietal development to planting. By so doing, it provides an in-depth analysis of farmer demand factors and their implications for adoption decisions in parallel with the supply-related institutional factors that shape the entire seed system. To the best of our knowledge, the paper is the first to analyze the process moving from variety development through the seed system to farmlevel adoption.

The paper is organized as follows. The next section discusses evidence on institutional and farm-level constraints to adoption of new varieties. Following this, the Moroccan seed system, from breeding to seed distribution, is described. This description highlights some conditions that hinder wider diffusion of improved varieties.

\section{Institutional obstacles to agricultural technology diffusion}

Several studies have investigated the implications of institutional factors in a country's ability to exploit the full potential of improved agricultural technologies (Spielman and Smale, 2017; Spielman et al., 2012; Smale et al., 2009; Nagarajan et al., 2008; Audi et al., 2008; David et al., 2002; Tripp and Rohrbach 2001; Gisselquist and Van Der Meer 2001; Hassan et al., 2001; Tripp and Louwaars 1997; Smale and Heisey 1994). Smale and Heisey (1994) discuss the case where the agricultural research complex in Malawi developed and released dent hybrid maize varieties while consumers had 
strong preference for flint varieties. Lack of attention to consumer/farmer preferences delayed diffusion of hybrids. Tripp and Rohrbach (2001) report that seed enterprise development in sub-Saharan Africa has been hampered by regulatory frameworks favoring parastatal enterprises and inhibiting commercial innovation. Provision by government and donor projects of large amounts of free or subsidized seed further discourages seed enterprise development.

David et al. (2002) found that low and fluctuating seed supply and inadequate varietal promotion efforts are important in undermining adoption. Spielman et al. (2012) examined the theoretical and practical roles of the public and private sectors, among others, in the seed system in Ethiopia. Spielman and Smale (2017) argue that undue emphasis is placed on varietal adoption while varietal turnover which has several benefits is neglected in South Asia and Africa South of the Sahara. While acknowledging the diversity of crops and socio-economic contexts and the limitations of a one-size-fits-all approach, the study suggests a sequence of short, medium, and long-term regulatory reforms and public investments to accelerate varietal turnover. Tripp and Louwaars (1997), Gisselquist and Van Der Meer (2001) and Hassan, et al. (2001) identified contestable property rights related to improvement of cultivated varieties, the absence of institutions for improved varieties, and information asymmetries in the exchange of seed between buyers and sellers as constraints that complicate early stages of seed market development. Turner and Bishaw (2016) and Setimela et al. (2009) conducted qualitative assessments of varietal release systems. These studies stress that some countries unnecessarily duplicate efforts by carrying a painstaking testing on varieties which were tested for wide adaptation and released by one or more neighboring countries with similar agro-ecologies.

With regard to adoption decisions, several studies showed that access to seeds is particularly important (Almekinders et al., 2019; Shiferaw et al., 2015; Dibba et al., 2015; Asfaw et al., 2011). Others examined how information about new varieties affects adoption (Simtowe et al., 2019; Diagne and Demont 2007) and still others stressed the importance of innovative marketing in the supply of seeds, especially to smallholders (Tripp, 1997).

\section{Wheat in Morocco}

\subsection{Description of the production system and varietal change}

Morocco is characterized by a wide variety of topographies ranging from mountains and plateaus to plains, oasis, and Saharan dunes. The country faces irregular rain patterns, extended periods of dry spells and wet periods with a regime of irregular precipitation, cold spells and heat waves (Lahlou et al., 2016). These conditions - typical of the Mediterranean climate, are increasingly resulting in droughts, which significantly affect agriculture. The country's long-term (20002019) average annual rainfall is $308 \mathrm{~mm}$ with $25 \%$ variation and average annual temperature of $29.7 \mathrm{oC}$.

In Morocco, agriculture in general and wheat production in particular exhibits a dichotomy between traditional subsistence-oriented production and market-oriented production. The traditional subsistence sector which accounts for about $85 \%$ of total agricultural areas consists of highly heterogenous farms with an average holding of 5.85 ha (std.dev. = 11.8 ) involved predominantly in low input cereal, legume, and livestock production which almost entirely depend on rainfall. With few exceptions in the mountainous regions, all tillage and harvesting operations in the rainfed areas are mechanized. The gross annual agricultural product is therefore strongly correlated to the annual rainfall and, due to the importance of the agricultural sector, each rainfall deficit is associated with significant impacts on the GDP. Market-oriented agriculture also comprising of heterogenous farms involving some small (up to only 2.1 ha) and some large (up to 200 ha) farms (std.dev. $=14.2$ ), which are highly mechanized, and more intensive with an average holding of 5.92 ha is concentrated in irrigated areas. Although the irrigated areas represent only $15 \%$ of agricultural lands, they contribute $45 \%$ to agricultural GDP and $75 \%$ of agricultural exports (Lahlou et al., 2016).

Until the start of the twentieth century, cereal cropping in Morocco was dominated by barley followed by durum wheat both of which were introduced by Arabs around the seventh century AD. In the early 1900s, bread wheat was introduced into Morocco by the French colonizers. The first bread wheat cultivars introduced were of Algerian origin. By 1929, bread wheat acreage reached 0.25 million ha, of which European cultivars constituted about $33 \%$. In the late 1940s, bread wheat area increased to between $0.3-0.4$ million ha while durum wheat area was about 1 million ha. Since the early 1980s, the government pursued an intensification policy which aimed at increasing bread wheat production through wider adoption of improved varieties. As a result, total wheat area increased to an average of 3 million ha between 2010 and 2018 with bread wheat constituting about 2 million ha. The policy incentives used to encourage the production of bread wheat included guaranteed producer prices and fixed marketing margins.

The wheat varieties introduced by the French colonizers were cultivated until the 1970s, but most went out of production afterwards. Low yield potential, limited response to fertilizers, late maturity and tall stature increasing susceptibility to lodging led to their abandonment (Nasserlhaq and Nachit 2006). Increasing wheat productivity is a fundamental goal of INRA. The INRA-CG partnership has been viewed as effective as national wheat yield increased from a 20 -year average 
of 0.92 ton/ha between 1961 and 1980 to about 1.18 ton/ha between 1981 and 2000, about a $28 \%$ increase. Yields in the later period are still far below the world average of over 3 ton/ ha and the African average of 2.3 ton/ha, reflecting the relatively harsh conditions for growing wheat and a challenge for the research complex (FAOStat 2017). In Morocco, the average number of wheat fields per family is 1.91 and each family on the average grows 1.4 wheat varieties. With few exceptions, almost all wheat species grown in the country are spring types.

Low productivity and increasing demand for wheat due to income and population growth has resulted in growing dependence on wheat imports. Imports reached about 5 million tons in 2016 (FAOStat 2017) valued at approximately US $\$ 1.75$ billion. Despite dependency on imports, wheat remains one of the most important staples in the Moroccan diet, consumed as bread and couscous. With a goal of lowering dependency on wheat imports, the government has invested heavily in wheat breeding. Over the last 20 years, this investment averaged about 0.25 million US\$ per year - making the wheat improvement program at INRA one of the leading programs in the North African region (INRA, n.d.).

\subsection{Wheat variety release and licensing, and seed multiplication and dissemination}

\subsubsection{Variety release}

Morocco follows a compulsory variety release system where both registration testing (Distinctness, Uniformity and Stability-DUS) and performance testing (Value for Cultivation and Use-VCU) are required for commercialization. A plant variety protection (PVP) system, introduced in 2002, provides the public and private sectors opportunities to protect and exploit variety rights. Under this system, breeders can enforce protection of their varieties through a licensing mechanism. All varieties from the national breeding programs or introduced from abroad can be submitted for registration in a national catalogue for release. Foreign varieties are treated and tested under similar conditions as those from the national programs.

\subsubsection{Testing procedures}

VCU trials are conducted according to an approved experimental protocol. Each variety is tested in multiple locations representing all the agro-ecologies and mega environments. All are compared to checks, one of which is selected from the best performing varieties recently registered and the other from the most widely cultivated varieties. In addition to VCU trials, DUS tests are needed for variety registration and to grant the plant breeder rights. Results of DUS tests are used to protect breeders' rights and for promotion to farmers.
For VCU tests, grain yield is the main criterion for release: a variety can only be released if the simple yield (averaged over all agro-ecologies) is higher than the best local checks in each location. The local checks may be different across locations. Other criteria, such as grain quality and pest tolerance, are taken into consideration, but in general, the new variety is approved only when it is significantly higher yielding than the simple mean of the checks. When the new variety is statistically at par with the mean of the checks, it could be proposed for release if it has certain key traits (disease tolerance, quality, etc.). Resistance to drought and diseases are not primary criteria for varietal release, reducing breeders' motivation to include these traits into their new varieties. Climate change is adversely affecting the distribution of rainfall and pests and diseases in wheat-growing areas with some areas affected more than others - thereby increasing the differences across locations. This creates an even greater incompatibility between the current practice of wide adaptation testing for registration and farmer trait preferences which vary across locations.

\subsubsection{Seed multiplication and distribution}

The Société Nationale de Commercialisation des Semences (SONACOS) was established in 1975 as the national parastatal body to produce and market seeds of INRA varieties and was required to pay royalties to INRA. Until 2000, the national committee for cereals in the Ministry of Agriculture decided which varieties should be multiplied by SONACOS. Most frequently, well-known varieties were promoted, limiting access to newly released varieties. After 2000, SONACOS was free to decide which varieties would be multiplied. As a result, it began to register old but widely adapted varieties from Europe for which it does not pay royalties. Since 1992, access to INRA varieties had opened to the private sector. Liberalization of the seed sector enabled the private sector to acquire varieties from INRA and to register varieties from international sources.

New INRA varieties are now offered through an open tender system. The license is granted based on the highest combined offer of royalty paid on certified seed sales and concessional fees. Since liberalization in 2000, the national seed sector has seen significant growth with total area covered by certified seed for all cereals and wheat reaching $19 \%$ and $22 \%$ of national cereal and wheat areas, respectively (Bishaw et al., 2019). Despite this change, survey results showed that $81 \%$ of the certified wheat seed is still provided by SONACOS and private seed companies cover only $19 \%$. Moreover, the informal seed sector (farmer-to-farmer exchange, purchase from unlicensed village-based seed producers, use of recycled seed, etc.) still predominates, as $67 \%$ of bread wheat seed and $84 \%$ of durum wheat is informally sourced (Bishaw et al., 2019). 


\subsubsection{Delivery to end users}

As part of the entire Moroccan seed system, the wheat seed sector consists of several important actors including the national agricultural research system composed of the wheat breeding program and other complementary programs including agronomy and pathology, public and private seed companies with networks of seed dealers, associations of seed growers and seed traders, and regulatory agencies. Regulatory institutions govern imports, production, and certification, while private seed companies supply domestic markets. More than 1200 seed growers are members of the professional associations of seed companies (AMSP) and produce seeds under contracts. ASMP is active in the sector and is influential in seed policy. At the bottom of the chain, nearly 140 accredited commercial seed dealers sell seeds directly to farmers and to distributors.

\section{Materials and methods}

Data were obtained from several sources. For the analysis of farmer demand for seed, data from a 2013 household survey was used. All data collected through the survey refer to the 2012 production season. The institutional analysis used secondary data from official documents and company records, published and unpublished reports, workshops, discussions, and interviews with different actors in the wheat sector. The two sets of factors related to diffusion were analyzed separately, and the results combined to make comprehensive evaluation of the entire variety development - variety adoption chain.

\subsection{The household survey}

According to the Ministry of Agriculture, Morocco is divided into $2 \mathrm{M}$ environments (Rainfed and Irrigated) which are subdivided into 6 agro-climatic zones-Favorable, Intermediate, Unfavorable South, Unfavorable Oriental, Mountainous, and Saharan zones. Cereal production in the Saharan and Unfavorable Oriental zones is essentially limited to barley. Therefore, this study focuses on the remaining four zones. A nationally representative sample survey was carried in 2013 covering 21 major wheat-producing provinces, accounting for about 0.85 million wheat growing farmers (79\% of national) and 2.1 million ha of wheat area (74\% of national). The survey covered all four agro-climatic zones in both the irrigated and rainfed mega environments where wheat is produced (Fig. 1).

The minimum sample size needed to ensure $95 \%$ confidence and at least $3 \%$ precision was determined to be a little over 1000 households. To compensate for effects of missing data, the survey included a total sample of 1230 farm households drawn using a stratified sampling approach where provinces, districts and villages were used as strata. The total sample was distributed proportionally across 292 villages from 56

Fig. 1 Coverage of the household survey in Morocco

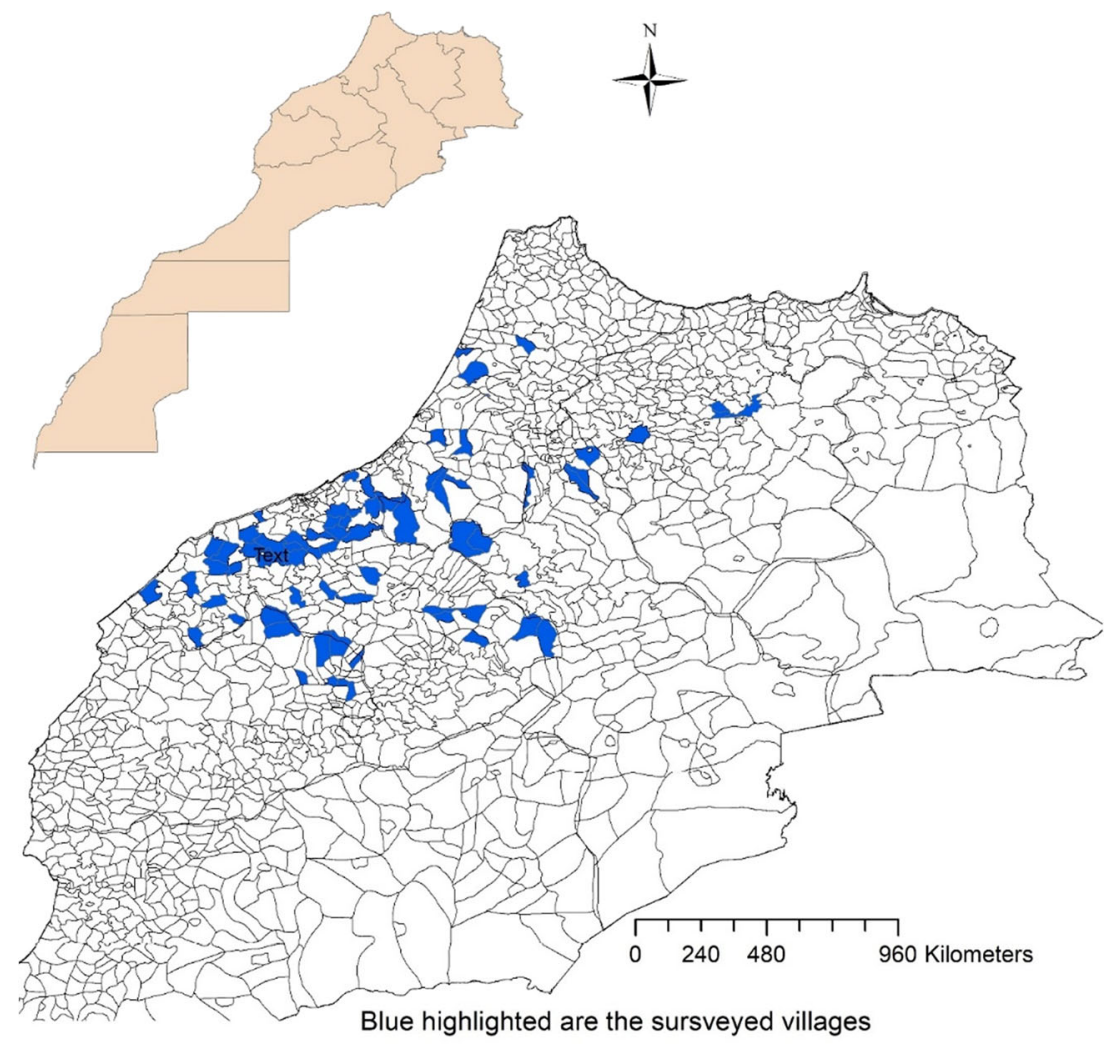


districts drawn randomly using a random number generator from the 21 provinces. Structured questionnaires were used to collect demographic, economic, social and consumption data. Detailed socio-economic, demographic, and production data were collected for households and the 2296 wheat fields cultivated by them.

\subsection{Determinants of adoption and adoption intensity}

To explain the low (42\%) adoption of more recent improved wheat varieties reported by Yigezu et al. (2019), an econometric analysis based on the double hurdle model (Cragg 1971) is employed. The double hurdle $(d h)$ framework incorporates the idea that the decision to adopt a new variety results from two sub-decisions: the first hurdle, determining whether the farmer would ever adopt, and the second, determining the intensity (area) of adoption (Amankwah et al., 2016).

We follow Feder (1980) in assuming that wheat farmers make decisions to adopt based on an objective to maximize expected utility. Factors affecting expected utility include yields, cost of production, cooking characteristics and others. Wheat production in the drylands of Morocco carries risk. Farmers are uncertain about profitability and consumption attributes of new varieties. Factors included in this analysis consist of micro-level factors and some supply side regional, district and village-level factors such as farmer characteristics (age, sex, education, off-farm income, whether the farmer hosted demonstration trial or participated in field days, etc.), farm characteristics (total area cultivated, agro-ecology in which the farm is located, whether the field is irrigated etc.) and institutional factors felt directly by farmers (access to credit, seed price, presence of seed dealers, etc.).

The basic idea in the $d h$ model is that, because of risk considerations, part of the sample is comprised of farmers who would never adopt, while others might, and the latter group's decision to adopt might be affected by different variables and in different ways than their decision about intensity of adoption. Following Yigezu et al. (2018), we specify the decision to use an improved wheat variety $\left(I W V_{i}^{*}\right)$ as:

$I W V_{i}^{*}=x_{1 i}^{\prime} \beta_{1}+\varepsilon_{1 i}$

Where the vector $x 1$ i reflects determinants of the adoption decision, $\beta 1$ are parameters, and $\varepsilon 1 \mathrm{i}$ is a normally distributed error term with mean zero and constant variance. The corresponding probit is estimated on the observed outcome $I W V_{i}=$ 1 if $I W V_{i}^{*}>0$ and 0 otherwise.

The desired area planted to an improved wheat variety (IWV) is also an unobserved latent value that can be specified as:

$A I W V_{i}^{*}=x_{2 i}^{\prime} \beta_{2}+\varepsilon_{2 i}$ where $\mathrm{X}_{2 \mathrm{i}}$ are determinants of area, $\beta_{2}$ are parameters and $\varepsilon_{2 \mathrm{i}}$ is a normally distributed error term. Since $A I W V_{i}^{*}$ is a latent variable, we work with observed area $\left(A I W V_{i}\right)$.

Observed area $=A I W V_{i}^{*}$ if $A I W V_{i}^{*}>0$ and $=0$ if $A I W V_{i}^{*} \leq 0$. Because we use observed area, the error term is a truncated normal distribution. The parameters $\beta_{1}$ and $\beta_{2}$ can be estimated separately because the Cragg likelihood function is separable; the marginal effects, however, need special attention (Burke 2009).

\subsection{Institutional analysis}

The institutional analysis started with a meeting between two seed system specialists, three crop breeders, a socio-economist, and manager of the country office from ICARDA and two senior breeders, director of the breeding program, and a socio-economist from INRA. The meeting had the principal objective of identifying main actors along the wheat seed value chain. This was followed by repeated visits to the major institutions identified during the meeting that comprise the value chain (Table 1). Meetings were held with officials to understand the role of each institution, its linkages with others, and their understanding and opinions about challenges and opportunities in the Moroccan wheat sector. Over a period of one year, a structured questionnaire was administered by the team of researchers to multidisciplinary representatives from the respective institutes in a key informant interview setting. The discussions were documented as part of information gathering. The analysis also included information from secondary data sources (such as the Bureau of Agricultural Statistics in the Ministry of Agriculture, The Société Nationale de Commercialisation des Semences (SONACOS), Office National de sécurité Sanitaire de Produits Alimentaires (ONSSA), Association Marocaine des Multiplicateurs de Semences (AMMS) and Association Marocaine des Semences et Plants (AMSP)), data from published and unpublished reports, and policy documents. This review also produced a pictorial representation of the wheat sector, information on the seed policy, and regulatory frameworks that guide system operations. The whole system was subsequently analyzed to identify bottlenecks and constraints to efficient functioning and opportunities for improvement. A draft report was shared with all stakeholders to obtain feedback and enhance the analysis. Finally, after incorporating all comments, a general meeting with over 30 participants drawn from all stakeholders (including the president of the association of seed professions which is an influential body in the country's seed policy formulation) was held and the main findings were presented, discussed, and validated. This meeting was chaired by the Director General of INRA who was subsequently charged with the establishment of a task force to 
Table 1 Moroccan institutions and seed system actors, with the representatives of which, the research team held key informant interviews

\begin{tabular}{|c|c|c|c|}
\hline Institution & Role in the Value chain & $\begin{array}{l}\text { Number of times visited/ } \\
\text { consulted }\end{array}$ & $\begin{array}{l}\text { Total number of } \\
\text { people } \\
\text { consulted } \\
\text { (interviewed) }\end{array}$ \\
\hline $\begin{array}{l}\text { Institut National de la Recherche Agronomique } \\
\text { (INRA) }\end{array}$ & $\begin{array}{l}\text { Develop new technologies (varieties, crop } \\
\text { management) }\end{array}$ & Twice & 14 \\
\hline $\begin{array}{l}\text { Office National de sécurité Sanitaire de Produits } \\
\text { Alimentaires (ONSSA) }\end{array}$ & $\begin{array}{l}\text { Variety release, variety protection, seed } \\
\text { certification }\end{array}$ & Twice & 3 \\
\hline $\begin{array}{l}\text { Société Nationale de Commercialisation des } \\
\text { Semences (SONACOS) }\end{array}$ & Seed production and marketing & $\begin{array}{l}\text { Several face to face } \\
\text { meetings with the head } \\
\text { of the commercialization } \\
\text { department }\end{array}$ & 1 \\
\hline $\begin{array}{l}\text { Association Marocaine des Multiplicateurs de } \\
\text { Semences (AMMS) }\end{array}$ & Contract seed production & Twice & 2 \\
\hline $\begin{array}{l}\text { Association Marocaine des Semences et Plants } \\
\text { (AMSP) }\end{array}$ & Seed traders & Once & 2 \\
\hline $\begin{array}{l}\text { Five major wheat traders involved in local } \\
\text { purchases and imports }\end{array}$ & $\begin{array}{l}\text { Purchase locally and/or import wheat and sale to } \\
\text { flour mills }\end{array}$ & Once each to all 5 of them. & 5 \\
\hline Association of seed growers & & Once & 5 \\
\hline Association of private seed companies & & Once & 2 \\
\hline $\begin{array}{l}\text { Policy and regulation desk in the Ministère de } \\
\text { l'Agriculture et de la Pêche Maritime (Ministry } \\
\text { of Agriculture and Maritime) }\end{array}$ & $\begin{array}{l}\text { Formulate of national agricultural policies and } \\
\text { regulations and agricultural plan }\end{array}$ & $\begin{array}{l}\text { Attended the final } \\
\text { workshop }\end{array}$ & 1 \\
\hline $\begin{array}{l}\text { Extension Department (Office National du } \\
\text { Conseil Agricole) in the Ministère de } \\
\text { l'Agriculture et de la Pêche Maritime (Ministry } \\
\text { of Agriculture) }\end{array}$ & $\begin{array}{l}\text { Define strategies for technology transfer and } \\
\text { extension services }\end{array}$ & Once & 3 \\
\hline $\begin{array}{l}\text { Fédération Nationale Interprofessionnelle des } \\
\text { Semences et Plants (FNIS) }\end{array}$ & $\begin{array}{l}\text { Represent seed growers, nurseries, and seed and } \\
\text { planting material traders }\end{array}$ & Once & 2 \\
\hline $\begin{array}{l}\text { The INRA senior plant breeders for durum, bread, } \\
\text { Barley, Faba bean and Chickpea }\end{array}$ & Variety development & One focus group discussion & 6 \\
\hline $\begin{array}{l}\text { Confederation of Moroccan Agriculture and Rural } \\
\text { Development (COMADER) }\end{array}$ & $\begin{array}{l}\text { A professional agricultural organization composed } \\
\text { of experts from the different nodes in the value } \\
\text { chains starting from production to processing } \\
\text { and marketing with the aim to achieve higher } \\
\text { level of synergy }\end{array}$ & Once & 1 \\
\hline
\end{tabular}

lobby for policy and institutional changes as per the recommendations of the study.

\section{Results and discussion}

We make distinction between two groups of varieties: 1) those which are currently being cultivated by farmers because their seeds are being produced and disseminated by SONACOS and the private seed companies (though there might still be availability and access issues); and 2) those which have been rejected during variety testing or those released but not being cultivated by farmers because no seed company is multiplying and selling their seeds. To explain the determinants of adoption for the first set of varieties, we apply the $d h$ model to data from a survey of 2296 fields. To explain the absence of the 2nd set of varieties in the Moroccan wheat fields, we carry out analysis of supply-side institutional factors preventing them from reaching farmers.
The presentation of the results begins with the findings of the analysis of survey data on the level of adoption of improved wheat varieties. Then, we present the results of the $d h$ model, followed by the results of the qualitative institutional analysis. The findings of the farmer-side and institutional analyses are combined to distill major factors responsible for low adoption.

\subsection{Diffusion of improved wheat varieties}

Adoption of more recent wheat varieties stands at low levels with only $16 \%$ and $41 \%$ of Moroccan wheat growers cultivating varieties released in the last 10 and 20 years, respectively. We computed the national average varietal replacement rate (VRR) as the area-weighted average number of years since the current variety has been cultivated first on each field in our sample. Higher values of VRR indicate that variety replacement is slow. With an area-weighted national VRR of once in 22 years, old varieties still predominate (Fig. 2); 


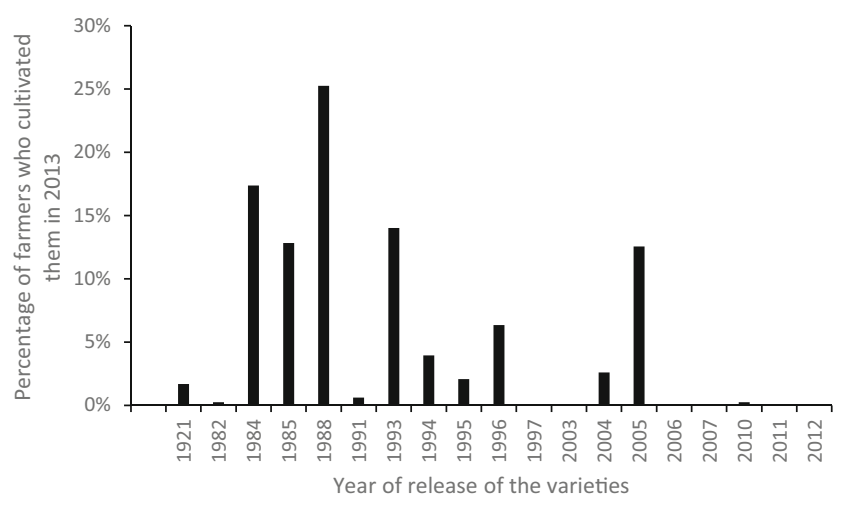

Fig. 2 Percentage of farmers who cultivated wheat varieties released in different years in the 2012 cropping season

this replacement rate is slow even by developing-country standards. For example, VRR in Kenya, Zimbabwe, and Afghanistan in 2014 were once in 6, 7 and 9 years, respectively (Lantican et al. 2016).

For the purpose of this study, a wheat variety is classified as an INRA-CG variety if it has genetic material that originated from the INRA-CG or has INRA-CG lines in its selection or any part of its pedigree. Adoption is defined as the use of any INRA-CG variety on any of a farmer's fields. Of 40 varieties cultivated by sample farmers, 18 are INRA-CG varieties, covering $79.4 \%$ of wheat area - showing the important role of the INRA-CG breeding program. However, of the 18 varieties, only nine of them were released after 1993 (i.e., they were less than 20 years old in 2013). These nine varieties covered only $20.4 \%$ of wheat area while the nine varieties released before 1993 covered about $58 \%$.

Survey results show that the average wheat seed replacement rate (regardless of source) is once in 2.1 years, which is rapid, even by developed world standards. However, only $22 \%$ of total seed used was certified $(17.8 \%$ from SONACOS and $4.2 \%$ from private seed companies) - showing a certified seed replacement rate of once in about 5 years, which is reasonable for a self-pollinating crop. The remaining $78 \%$ come from other sources including own-saved seed (51\%), local seed dealers (13.3\%), and seed dealers in neighboring villages $(13.4 \%)$, and cooperatives $(0.1 \%)$. The fast seed replacement rate along with slow varietal replacement suggest that farmers recognize the advantage of replacing seed frequently but raises the question of why old varieties continue to be cultivated, even with new seeds.

\subsection{Performance of INRA-CG}

Table 2 shows the contribution of the INRA-CG to the total number and acreage of improved varieties released since 1982. During 1982-1997 the INRA-CG partnership was successful. Since 1998, only 10 varieties were released, and none were being planted in the 2013 survey. Survey results show that $82.5 \%$ of wheat area in 2013 was cultivated with varieties released during 1982-1997. Of this, 96\% of area under improved varieties $(79.2 \%$ of national area) was planted with INRA-CG varieties - showing that the partnership produced

Table 2 Trends in the contribution of INRA-CG in varietal release and covering the Moroccan wheat area by improved varieties

\begin{tabular}{|c|c|c|c|c|c|c|c|}
\hline Period & $\begin{array}{l}\text { Total } \\
\text { number of } \\
\text { varieties } \\
\text { released }\end{array}$ & $\begin{array}{l}\text { Average } \\
\text { annual rate } \\
\text { of varietal } \\
\text { release }\end{array}$ & $\begin{array}{l}\text { Number of } \\
\text { INRA-CG } \\
\text { varieties re- } \\
\text { leased }\end{array}$ & $\begin{array}{l}\text { Number of wheat } \\
\text { varieties } \\
\text { cultivated by } \\
\text { farmers in } 2013^{*}\end{array}$ & $\begin{array}{l}\text { Wheat area covered } \\
\text { in } 2013 \text { by all } \\
\text { varieties released in } \\
\text { this period }(\%)\end{array}$ & $\begin{array}{l}\text { Number of varieties } \\
\text { originating from } \\
\text { CG_INRA that were } \\
\text { cultivated by farmers in } \\
2013\end{array}$ & $\begin{array}{l}\text { Wheat area covered in } \\
2013 \text { by the INRA_CG } \\
\text { varieties released in this } \\
\text { period }(\%)\end{array}$ \\
\hline $\begin{array}{l}\text { Unknown } \\
\text { release } \\
\text { date }\end{array}$ & 0 & NA & 0 & 7 & 0.34 & 0 & 0.00 \\
\hline 1949-1981 & 7 & 0.21 & 7.00 & 1.00 & 1.01 & 1 & 0.26 \\
\hline 1982-1986 & 14 & 2.80 & 12.00 & 4.00 & 34.67 & 4 & 33.57 \\
\hline 1987-1992 & 24 & 4.80 & 15.00 & 4.00 & 26.74 & 4 & 24.88 \\
\hline 1993-1997 & 53 & 13.25 & 14.00 & 14.00 & 21.11 & 9 & 20.70 \\
\hline 1998-2002 & 9 & 2.25 & 1.00 & 1.00 & 0.00 & 0 & 0.00 \\
\hline 2003-2007 & 25 & 6.25 & 6.00 & 7.00 & 15.98 & 0 & 0.00 \\
\hline 2008-2012 & 39 & 9.75 & 3.00 & 2.00 & 0.15 & 0 & 0 \\
\hline 2013-2015 & 12 & 6.00 & 0.00 & DK & DK & 0 & 0 \\
\hline Total & 183 & 2.77 & 58 & 33 & 100.00 & 18 & 79.41 \\
\hline
\end{tabular}

*NB: Out of 40 varieties cultivated by farmers in 2013, the release dates and the breeding programs from which they originated was identified for only 33. There rest could be either local land races or old improved varieties the release date and breeding program of which are unknown

Source: Varietal release data was obtained from the official release catalog for 2015 (http://www.onssa.gov.ma/fr/controle-des-semences-et-plants/ homologation-des-varietes). Area under improved varieties is estimated using the data obtained from the nationally representative sample of 2296 wheat fields which were surveyed in 2013 
Table 3 Results of the Double Hurdle (DH) model

\begin{tabular}{|c|c|c|c|c|}
\hline \multirow{2}{*}{$\begin{array}{l}\text { Variables } \\
\text { Tier1 (Imp. Var: } 1=\text { Yes, } 0=\text { No) }\end{array}$} & \multirow[t]{2}{*}{ Coef. } & \multirow[t]{2}{*}{ Std. Err. } & \multicolumn{2}{|c|}{ Marginal Effects } \\
\hline & & & $\mathrm{dy} / \mathrm{dx}$ & Std. Err. \\
\hline Age of household head (years) & 0.013 & $0.004^{* * *}$ & 0.001 & $0.000^{* * *}$ \\
\hline Sex of household head (1 = Male) & 0.604 & $0.245^{*}$ & 0.056 & $0.023^{* *}$ \\
\hline Education of household head (years) & 1.864 & $0.120^{* * * *}$ & 0.174 & $0.008^{* * * *}$ \\
\hline Access to credit $(1=$ Yes $)$ & 0.710 & $0.108^{* * *}$ & 0.066 & $0.010^{* * * *}$ \\
\hline Off_farm_Income ( 1 = Yes $)$ & -0.533 & $0.146^{* * *}$ & -0.050 & $0.013^{* * *}$ \\
\hline Total_wheat_area_cultivated (ha) & -0.002 & 0.005 & 0.000 & 0.001 \\
\hline Farmer hosted demonstration trials $(1=$ Yes $)$ & 1.557 & $0.465^{* * *}$ & 0.145 & $0.043^{* * *}$ \\
\hline Farmer visited field days(1 = Yes) & 0.472 & 0.432 & 0.044 & 0.040 \\
\hline Distance_to_seed_source $(\mathrm{km})$ & -0.081 & $0.006^{* * *}$ & -0.008 & $0.000^{* * *}$ \\
\hline Seed_company_present_in_village $(1=$ Yes $)$ & 0.608 & $0.143^{* * * *}$ & 0.057 & $0.013^{* * *}$ \\
\hline Agro_dealers_agrovets_in_village_(1 = Yes $)$ & -0.207 & $0.109^{*}$ & -0.019 & $0.010^{*}$ \\
\hline Price_of_seed_in_the_village (MAD/kg) & 0.058 & 0.064 & 0.005 & 0.006 \\
\hline Farm_is_in_the_favorable_zone $(1=$ Yes $)$ & 1.650 & $0.143^{* * *}$ & 0.154 & $0.011^{* * * *}$ \\
\hline Farm_is_in_the_intermediate_zone $(1=$ Yes $)$ & 0.662 & $0.151^{* * * *}$ & 0.062 & $0.014^{* * * *}$ \\
\hline Farmer had problem_getting_herbicide $(1=$ Yes $)$ & -0.231 & 0.225 & -0.021 & 0.021 \\
\hline Is_your_wheat_field_irrigated $(1=\mathrm{Yes})$ & 0.055 & 0.145 & 0.005 & 0.014 \\
\hline cons & -5.251 & $0.440^{* * * *}$ & & \\
\hline \multicolumn{5}{|l|}{ Tier2 (Are under Imp. Var ha) } \\
\hline Total_wheat_area_cultivated (ha) & 1.000 & $1.06 \mathrm{E}-10^{* * *}$ & 0.131 & $0.000^{* * * *}$ \\
\hline Distance_to_seed_source $(\mathrm{km})$ & $-8.98 \mathrm{E}-11$ & $1.56 \mathrm{E}-10$ & 0.000 & 0.000 \\
\hline Seed_company_present_in_village $(1=$ Yes $)$ & $6.88 \mathrm{E}-09$ & $3.10 \mathrm{E}-09^{* *}$ & 0.000 & $0.000^{* *}$ \\
\hline Agro_dealers_agrovets_in_village_(1 = Yes $)$ & $-1.33 \mathrm{E}-09$ & 2.77E-09 & 0.000 & 0.000 \\
\hline Price_of_seed_in_the_village (MAD/kg) & $-5.42 \mathrm{E}-10$ & $1.68 \mathrm{E}-09$ & 0.000 & 0.000 \\
\hline Farm_is_in_the_favorable_zone $(1=$ Yes $)$ & $-3.01 \mathrm{E}-09$ & $5.22 \mathrm{E}-09$ & 0.000 & 0.000 \\
\hline Farm_is_in_the_intermediate_zone $(1=$ Yes $)$ & $-3.97 \mathrm{E}-09$ & $5.72 \mathrm{E}-09$ & 0.000 & 0.000 \\
\hline cons & -2.000 & $6.45 \mathrm{E}-09^{* * * *}$ & & \\
\hline Sigma_intercept & $3.65 \mathrm{E}-08$ & $9.46 \mathrm{E}-10^{* * * *}$ & & \\
\hline Chi-square (16 df) & 552.410 & $P<0.0001$ & & \\
\hline
\end{tabular}

**** ${ }^{* *},{ }^{*}$ indicate significance at $0.01,0.05$ and 0.1 levels

varieties with durable presence. Since 1998, however, the partnership has been far less effective as judged by variety diffusion.

Immediately after INRA-CG started releasing varieties in 1982, the varietal release rate jumped to a five-year average of 2.8 per year. The rate continued to increase, reaching a peak of 13.25 in 1993-1997. The rate decreased substantially in the subsequent period (1998-2002) to 2.25, with moderate increases since (Table 1). The 1993-1997 period was especially remarkable because $24 \%$ of all INRA ${ }^{1}$ releases occurred during it. Of 14 varieties cultivated by farmers in 2013 which were released during 1993-1997, 9 were of INRA-CG origin, covering about $20.7 \%$ of the wheat area. INRA's internal records show that 30 varieties from INRA-CG were submitted for release between 1998 and 2012 but only ten were released,

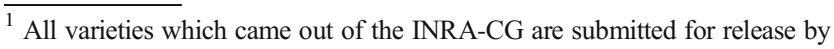
INRA.
}

and none were detected in the survey. The post-1998 decline in releases leads to questions about institutional constraints.।.

\subsection{Factors affecting the propensity and intensity of adoption of disseminated varieties}

Availability of adequate quantities of certified seeds of most recent varieties does not always translate into wide adoption by farmers. Variety traits may not be desirable or other factors including access to credit and farm and farmer-related socioeconomic constraints might limit adoption. Table 3 reports results of the $d h$ model (coefficients and marginal effects are presented in columns 2 and 4, respectively). In the same way availability and access affect food security (Sen, 1981), they also affect seed security. We use distance to seed source, presence of a seed company in the village, presence of an agrovet (which at times also sell agricultural inputs including seeds) as 
proxies for seed availability. Moreover, we used price of seed and access to credit as proxies for access to seed because higher seed prices and poor access to credit might limit ability to purchase seed even when the farmer is interested and seeds are available in the market. Even when farmers are interested and have the financial means to pay for certified seeds, the distance to the seed source and availability of seed dealers in the village can prevent them from buying it. If seed sources are far away, implying higher transactions costs, the ability of poorer farmers to access seeds can be reduced - indicating that distance to seed source is related to both seed availability and access.

By summing the marginal effects of all six institutional constraints for adoption (access to credit, presence of a seed company in the village, presence of agrovets, price of seed, and access to herbicides), it is seen that these factors reduce the probability of adoption of varieties released after 1993 (and before 1998) by only 15 percentage points. Thus, farmer-level and local constraints contribute to lower adoption of improved varieties. However, for post-1998 releases, an analysis of farmer and local institutional factors is not necessary as no farmers have been found to plant these varieties. We turn to other institutional constraints to explain the lack of diffusion of post-1998 varieties.

For the 15-20-year-old varieties, three variables alone-not hosting demonstration trial, not participating in field days and not being in the favorable zone-reduce the propensity to adopt by $51 \%$. Farmer conditions and agro-ecological heterogeneity have a strong effect on low adoption of these varieties. During our survey, we asked farmers to rank the importance of different traits in their adoption decisions. Analysis revealed that there are important traits beside yield that farmers value and preferences vary by agro-ecology (Table 4). For example, farmers in unfavorable regions have a stronger preference for higher straw yield because in unfavorable regions, livestock are the main source of livelihoods. These results indicate that the multilocation testing for variety release is not helping in meeting the diverse preferences of farmers in different agro-ecologies possibly contributing to the low adoption. Alary et al. (2020) also carried an in-depth analysis and concluded that some breeding objectives in Morocco may not be perfectly aligned with farmers' trait preferences.

In the face of wide adaptation testing for yield, mismatches between some breeders' objectives and farmer demands are expected. This however is unlikely for the INRA-CG because the most recent varieties were selected from the more than 20year-old farmer-preferred INRA-CG varieties which still cover over $50 \%$ of total wheat area. During our survey, farmers were asked whether they have heard about the new Hessian fly-resistant durum wheat variety from INRA-CG called Faraj which was released in 2007 and is hailed by breeders as one of the best available varieties. The results showed that only $4 \%$ responded "Yes" - showing that farmers don't even know that the new INRA-CG varieties exist and hence the discussion on adoption of these varieties becomes irrelevant. Therefore, for most recent varieties, institutional factors affecting seed release, availability, and extension service delivery systems should explain low adoption.

\subsection{Challenges in variety development, licensing, release, and dissemination in Morocco}

\subsubsection{Challenges faced by INRA: variety testing protocols}

Discussions during a workshop with stakeholders revealed that three issues undermine widespread diffusion of newer INRA-CG varieties. First, while many more varieties with substantially higher yields in their specific recommendation domains were submitted by INRA for testing since 1998, most were discarded during DUS and VCU trials. To take advantage of specific traits for targeted environments, since the late 1980s, INRA-CG has adopted the strategy of breeding for specific adaptation. As a result, the program started breeding varieties separately for each mega-environment recognizing that varieties bred for one may not perform well in the other. The INRA-CG varieties with specific adaptation started to be submitted in the 2 nd half of the 1990s. The broad adaptation testing regime implied by the DSU and VCU along with the emergence of private seed companies in early 1990s which started importing old European varieties with wide adaptation made it difficult for post-1998 INRA-CG varieties to be formally released.

While wheat is generally known to be a widely adapted crop, some varieties bred for a specific agro-ecology or mega environment may not necessarily outperform the best local checks in other agro-ecologies or mega-environments. As a result, after 1998, many varieties from INRA-CG with substantial potential in the specific agro-ecologies they were bred for have been discarded because of low performance outside their recommendation domains. Experts identify this as the main explanation for the problem of the low release rate of new varieties, especially after 1998. Application of this stringent release criterion for all varieties deprives farmers access to potentially beneficial varieties specifically adapted to their agro-ecologies. Testing has created a bottleneck between the breeding program and farmer demands.

Analysis of the survey data by agro-ecological zone (AEZ) confirms these perceptions. Yield among certified seed users in irrigated and rainfed areas of the Unfavorable South AEZ respectively average 4.77 tons/ha and 1.14 tons/ha which are $24 \%$ and $23 \%$ higher than corresponding yields in the Mountainous AEZ. Likewise, yield among uncertified seed users in the irrigated and rainfed areas of the Favorable AEZ are 4.22 tons/ha and 0.81 tons/ha, respectively, $18 \%$ and $13 \%$ higher than corresponding farmers in the Mountains AEZ. In addition to the presence of low-yielding landraces in the Mountains AEZ, results confirm substantial differences in 
Table 4 Farmers' ratings of wheat traits in terms of their importance for varietal adoption decision at national and agroecological ${ }^{\mathrm{a}}$ levels $\left(1=\mathrm{most}^{\mathrm{s}}\right.$ important and $27=$ least important)

\begin{tabular}{|c|c|c|c|c|c|}
\hline \multirow[t]{2}{*}{ Trait } & \multicolumn{5}{|l|}{ Average rating $\sim$} \\
\hline & National $(n=1230)^{\wedge}$ & Favorable $(n=456)$ & Intermediate $(n=364)$ & Unfavorable South $(n=259)$ & Mountainous $(n=151)$ \\
\hline Grain yield & 1 & 1 & 1 & 1 & 1 \\
\hline Grain yield stability & 2 & 3 & 2 & 10 & 3 \\
\hline Flour making quality & 3 & 4 & 3 & 3 & 4 \\
\hline Marketability (demand) & 4 & 2 & 7 & 6 & 2 \\
\hline Grain color & 5 & 6 & 4 & 5 & 9 \\
\hline $\begin{array}{l}\text { Guaranteed minimum } \\
\text { yield }\end{array}$ & 6 & 9 & 5 & 13 & 5 \\
\hline Bread making quality & 7 & 10 & 8 & 4 & 8 \\
\hline Baking quality & 8 & 11 & 11 & 8 & 7 \\
\hline Taste for different dishes & 9 & 14 & 17 & 7 & 6 \\
\hline Drought tolerance & 10 & 5 & 9 & 16 & 12 \\
\hline Straw yield & 11 & 16 & 6 & 2 & 17 \\
\hline Grain size & 12 & 13 & 14 & 9 & 10 \\
\hline Tillering ability & 13 & 7 & 10 & 11 & 18 \\
\hline Early maturity & 14 & 8 & 12 & 12 & 13 \\
\hline Better grain price & 15 & 15 & 19 & 19 & 11 \\
\hline Storability & 16 & 12 & 16 & 17 & 19 \\
\hline Other food making quality & 17 & 17 & 13 & 15 & 15 \\
\hline Grain shape & 18 & 18 & 15 & 14 & 16 \\
\hline Palatability of straw & 19 & 20 & 20 & 20 & 14 \\
\hline Less fertilizer demand & 20 & 21 & 18 & 21 & 24 \\
\hline Water-logging tolerance & 21 & 19 & 24 & 23 & 20 \\
\hline Shattering tolerance & 22 & 23 & 24 & 18 & 23 \\
\hline Disease tolerance & 23 & 22 & 21 & 23 & 22 \\
\hline Insect tolerance & 24 & 24 & 24 & 23 & 21 \\
\hline Threshability & 25 & 26 & 22 & 22 & 25 \\
\hline Frost tolerance & 26 & 25 & 23 & 23 & 26 \\
\hline Labor demand & 27 & 27 & 24 & 23 & 26 \\
\hline
\end{tabular}

According to the Ministry of Agriculture (MoA), Morocco is divided into 6 agro-ecological zones. These are the Favorable zone, the Intermediate zone, the Unfavorable South zone, the Unfavorable Oriental zone, the Mountainous zone and the Saharan zone. Cereal production in the Saharan and Unfavorable oriental zones is essentially limited to barley and hence these zones were excluded from this survey

$\sim$ The ratings provided by farmers were averaged first for each agro-ecology. Then, we used the number of farmers in each agro-ecology as weights for aggregation of these ratings to the national level

${ }^{\wedge}$ Different numbers of farmers out of the total sample rated the traits. A total of 1182 farmers provided their ratings for all or some of the traits while 48 didn't rate any of the traits. Out of the 1182 farmers who gave their ratings, all of them provided their ratings on the importance of yield in their varietal adoption decision while some of them didn't provide their ratings for all or some of the other traits. Grain shape was the trait which was rated by the least number (141) of farmers

yield potential across agro-ecologies under similar irrigation and seed types. Importantly, for example, the durum wheat variety Carioca has the second highest yield in the irrigated environments but one of the lowest yields in rainfed agroecologies (Table 5).

Looking at the farmer-reported yield distribution by AEZ instead, Carioca has the second highest yield in the Favorable AEZ while it is among the three lowest yielders in the intermediate AEZ (Fig. 3). Another durum wheat variety (Karim) has one of the lowest average yields in irrigated and rainfed areas, (3.56 and 0.84 tons/ha respectively) but the highest yields in both the Intermediate and Unfavorable zones. The Intermediate and Unfavorable zones constitute less than half of national wheat area and lower yields in the favorable and mountainous AEZ weigh the average yield down.

\subsubsection{Challenges faced by INRA: licensing protocols}

Analysis of the historical varietal licensing data also revealed that some seed companies which purchased the licenses to the 
Table 5 Varietal yield comparisons of wheat by mega environments in Morocco

\begin{tabular}{|c|c|c|c|c|c|c|c|c|c|}
\hline \multirow[t]{2}{*}{$\begin{array}{l}\text { Variety } \\
\text { Name }\end{array}$} & \multirow[t]{2}{*}{$\begin{array}{l}\text { Release } \\
\text { date }\end{array}$} & \multirow[t]{2}{*}{ Released by } & \multicolumn{2}{|c|}{ Adoption } & \multicolumn{2}{|c|}{$\begin{array}{l}\text { Adoption } \\
\text { Rank* }\end{array}$} & \multicolumn{3}{|c|}{ Average Yield (kg/ha) } \\
\hline & & & $\begin{array}{l}\text { Area } \\
(\%)\end{array}$ & $\begin{array}{l}\text { Farmers } \\
(\%)\end{array}$ & Area & Farmers & $\begin{array}{l}\text { Irrigated }(\mathrm{w}= \\
17 \%)\end{array}$ & $\begin{array}{l}\text { Rainfed }(\mathrm{w}= \\
83 \%)\end{array}$ & $\begin{array}{l}\text { Area } \\
\text { weighted }^{\wedge}\end{array}$ \\
\hline Radia & 2005 & Florimond desprez & 10.24 & 6.32 & 5 & 6 & 3915 & 896 & $1409(1407)$ \\
\hline Carioca & 2005 & Serasem & 2.54 & 2.4 & 8 & 10 & 2482 & 298.43 & $670(1551)$ \\
\hline Arrehane & 1996 & INRA-CG & 7.09 & 3.61 & 7 & 7 & 2002 & 725.7 & 943(1009) \\
\hline Wissam & 1995 & $\begin{array}{l}\text { Ets lemaire } \\
\text { deffontaine }\end{array}$ & 2.17 & 2.48 & 10 & 9 & Not grown & 323.73 & $269(217)$ \\
\hline Amal & 1993 & INRA-CG & 12.45 & 9.84 & 3 & 5 & 4016 & 588.91 & $1171(1069)$ \\
\hline Achtar & 1988 & INRA-CG & 22.2 & 18.9 & 1 & 2 & 3908 & 1021 & $1512(1445)$ \\
\hline Saidi (Saada) & 1988 & INRA-CG & 2.45 & 3.14 & 9 & 8 & 896 & 235.5 & $348(209)$ \\
\hline Karim & 1985 & INRA-CG & 12.31 & 19.21 & 4 & 1 & 3285 & 799.9 & $1222(928)$ \\
\hline Marchouch & 1984 & INRA-CG & 13.01 & 14.07 & 2 & 3 & 2198 & 853.1 & $1082(988)$ \\
\hline Marzak & 1984 & INRA-CG & 8.25 & 11.37 & 6 & 4 & 2979 & 549.1 & $962(984)$ \\
\hline
\end{tabular}

$\wedge$ In Morocco $17 \%$ of wheat area is irrigated while the remaining $83 \%$ is rainfed

* Adoption rank refers to the rank of the variety in terms of the number of farmers cultivating it or in terms of the area it covers. The variety which is ranked 1 is the most adopted, the variety ranked 2 is the 2 nd most adopted, etc. Values in brackets are standard errors

ten INRA-CG varieties released after 1998 have not produced distributed these varieties. This provides a partial explanation for the absence in farmer fields of INRA-CG varieties released after 1998. Multiplication and marketing new varieties takes time, effort, and investment. Even after investing in seed multiplication, a variety requires large investments in extension, demonstration, and popularization. Seed companies are not willing to incur these costs as long as they have the option of selling the old varieties for which they have already made the investment. As a result, some seed companies were taking advantage of an ill-conceived and faulty variety licensing contract given by INRA.
Breeding programs in other countries with royalty fees ensure production and dissemination of their varieties by developing contracts that include a clause specifying a mandatory minimum level of commercialization. In this way, breeding programs determine the minimum production level and fees so that it will be unprofitable for the company to purchase the license and not disseminate the seeds. The contract is designed to make it in the financial interest of the seed company to produce and market the new variety by making the necessary investment in awareness creation and marketing.

The licensing system for INRA varieties which existed until 2017 granted exclusive rights to a variety upon its purchase without any other obligation on the seed company's
Fig. 3 Average yields of top 10 wheat varieties covering $92 \%$ of total wheat area in Morocco

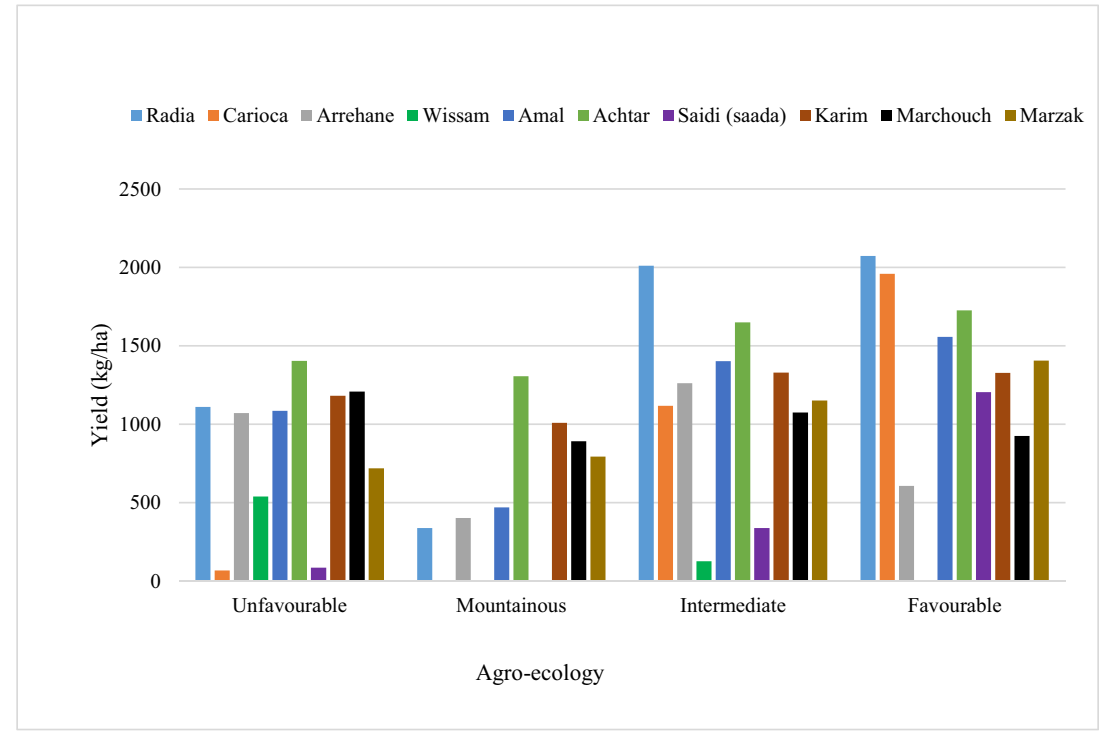


side. The contract does not specify the minimum royalty fees to be paid regardless of seed sales. Some small seed companies purchased licenses for INRA-CG varieties but did not produce and commercialize the seed. During the stakeholder meeting, INRA and ICARDA breeders along with experts from SONACOS argued that this was an intentional act by private seed companies to ensure that seeds of their old but still popular varieties will continue to maintain their market share. Therefore, the flaw in the licensing contract could be a major culprit for limited dissemination of seeds.

\subsubsection{Challenges faced by INRA: seed distribution entities}

In the past, INRA produced and provided start-up material (pre-basic seed) to seed companies for further multiplication. It stopped doing so in the early 2000s. Moreover, INRA started charging royalty and concessional fees for acquisition of new nationally bred public varieties. As a result, SONACOS and private seed companies have chosen to produce and market old varieties in which they have already invested and import pre-basic and basic seeds of 'obsolete' foreign (mainly European) wheat varieties. The Plant Variety Protection (PVP) of these obsolete varieties has expired and the companies are under no obligation to pay royalties. These varieties were bred for wide adaptation and can easily pass the tests for varietal release.

Access to INRA-CG varieties was opened to private actors in 1990, encouraging entry of private sector players and increasing interest in licensing varieties. However, after 30 years of the policy change, the current market shares of private seed companies in the cereal sector is a miniscule $5 \%$ of total seed use, but $19.1 \%$ of certified seed use, with only five companies participating. In contrast, private sector actors play major roles in wheat seed delivery in countries like India, Iran, Pakistan, and Turkey. The state-dominated wheat seed sector in Morocco is a result of production and marketing requirements which are punitive to small seed companies. This enabled continued dominance of SONACOS which benefits from large-scale prior investments in infrastructure and marketing networks. Moreover, SONACOS continues to receive government support. Currently, subsidies are given to seed companies based on sales volumes, enabling the companies to dictate what varieties to multiply and market.

\subsection{Combining the two analyses}

\subsubsection{Replacement rates and use of newer varieties}

Most wheat varieties cultivated in 2013 were already more than 15 years old when farmers began cultivating them. Specifically, most adoption of these older varieties occurred after 2000 (Fig. 4) - showing that they were already old when the farmers first planted them. There are three possible explanations for this phenomenon. First, policy changes in 1990 allowing private seed companies to release varieties could have motivated some farmers to adopt varieties released after 2000. After 2000, nine varieties were released by the private sector and the top-two of these varieties alone covered about $12.7 \%$ of wheat area in 2013. Second, as mentioned earlier, the national committee for cereals in the Ministry of Agriculture decides which variety should be multiplied by SONACOS and mostly old well-known varieties were promoted even after 2000. Third, in 1999, record high precipitation resulted in a bumper harvest. Throughout the early 2000s, the frequency of high rains during the planting season increased. As improved varieties are generally more responsive to fertilization in the presence of adequate moisture, this could possibly have motivated more farmers to adopt varieties which are newer than those that they had been cultivating until 2000 .

\subsubsection{Explaining the small effects of seed-related factors on adoption}

As argued in the introduction, adoption of improved varieties is determined by macro-level institutional and micro-level demand factors. Results of analyses focusing only on either side alone can be misleading. While farm-level and local factors affect adoption of new varieties (pre-1998 releases), they do not explain lack of adoption of post 1998 releases. Adoption of post-1998 releases is likely to be affected by similar local and farm-level characteristics, but the institutional failures in diffusion have led to failure to make these varieties available to farmers. Thus, institutional factors are, the main culprit.

Most farmers are not aware of new varieties that are released but not popularized, and their seed is not produced and disseminated. Their choice is limited to varieties offered by seed companies. If they were offered more recent varieties, some may have adopted them, particularly those bred for their specific agro-ecologies. Varieties which were bred for specific adaptation (including those from INRA-CG) but rejected during wide adaptation testing by ONSSA do not reach farmers.

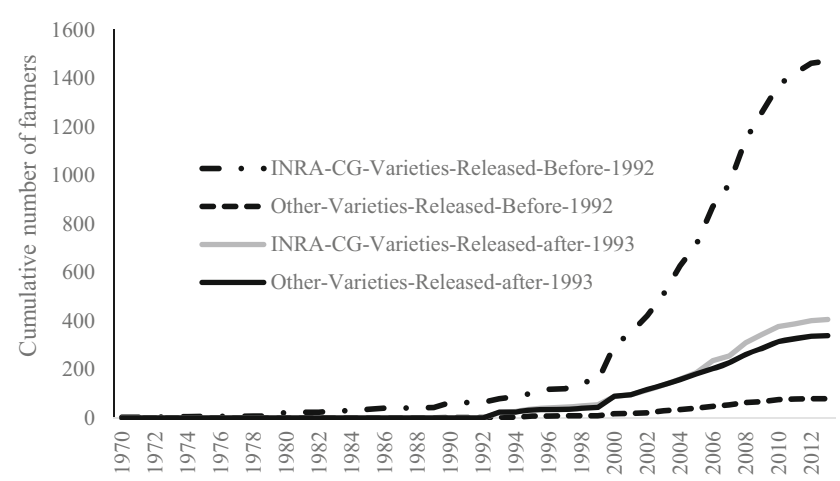

Fig. 4 Exposition of when sample farmers started growing the wheat varieties which they cultivated in 2012 
Farmers might be using old varieties due to lack of better alternatives. Were seeds of the INRA-CG varieties released after 1998 produced and disseminated, they stand higher chances to receive wider acceptance because they contain the important traits of the popular, but older INRA-CG varieties that predominate in Moroccan wheat fields. The varieties released after 1998 also have improvements in some traits including higher yields and resistance to hessian fly which is a growing problem for wheat production in Morocco.

Analysis of responses to questions during the survey about specific recent released INRA-CG varieties showed that most farmers are not aware of their existence and when they are, seeds are not available. Lack of information and the failure of the seed companies to supply the market provide part of the explanation for the dominance of old wheat varieties and these problems are clearly related to institutional failings. An institutional analysis uncovers explanations for this apparent failure in the seed systems.

\section{Conclusions and recommendations}

Low adoption of agricultural technologies in the developing world poses a major challenge to development efforts. In addition to farmer and localized environmental factors, institutional factors, including processes for variety development, testing, release, and licensing and seed production and commercialization, play important roles in explaining variety diffusion.

Taking improved wheat varieties in Morocco as a case study, this study examined challenges of the joint public and CGIAR wheat breeding program in achieving impact at scale by developing wheat varieties that subsequently became widely used by farmers. Few recent varieties from the breeding program have been released since 1998 and none are being cultivated by farmers. The failure of the breeding program to have an impact is evident in various forms. First, most farmers (58\%) cultivate varieties which are more than 20 years old. Second, the average seed replacement rate is 2.1 which is fast even by the developed countries standards, so there is little evidence that farmers do not adopt due to credit or behavioral obstacles. Third, the analysis of pre-1998 releases showed that removing the micro-level constraints limiting access to seeds would increase a typical farmers' propensity to adopt improved varieties by only $15 \%$. While this is the case for older varieties, the seeds of which are being disseminated by seed companies, the answer to the lack of diffusion of newly developed varieties required analysis of the institutional factors affecting variety availability.

Of 30 INRA-CG varieties submitted for release between 1998 and 2012, 20 were rejected during testing for variety release. A main reason for such a high rejection rate is that the INRA-CG shifted its breeding strategy toward specific adaptation, but the testing protocols did not change. Stringent national testing procedures for varietal release involve wide adaptation testing which prevents release of potentially useful varieties. These same varieties would have high chances of being widely accepted by farmers in their specific recommendation domains. By systematically discriminating against specifically adapted genotypes, wide adaptation-testing inadvertently promotes/prevents agrobiodiversity erosion/enrichment.

Ten INRA-CG varieties passed the stringent DUS and VCU tests by ONSSA and were released after 1998. These varieties were released because they out-yielded all local checks in all agro-ecologies. Moreover, these new varieties contain the important traits of the old varieties from the breeding program that are still under cultivation. However, these new INRA-CG varieties are not reaching farmers because the variety licensing contract used by INRA had a flaw which some seed companies exploited to defend their lucrative turf. Even though these companies control only a small portion of the market, they purchased the licenses of new INRA-CG varieties and put the varieties on the shelf - ensuring that no other seed company has the access to them. By doing so, they are able to stay on the market selling seeds of relatively older varieties because, promotion of a new variety has high cost which seed companies are not willing to incur.

The Moroccan seed market is characterized by a skewed distribution of market power where a large parastatal supplies $81 \%$ of the total certified wheat seed while the remaining five small private seed companies supply only $19 \%$. The power imbalance is important. After the circulation of the initial draft of Bishaw et al. (2019), the variety licensing contract offered by INRA has been revised including a clause requiring the licensee to produce a minimum amount of seed of the licensed variety.

Institutional factors have a major role in preventing diffusion of the most recent improved wheat varieties from INRACG. Once wheat varieties are disseminated, farmer-level factors become more important. Examining institutional and local factors together reveals that once seed companies decide to purchase the license and produce its seed, they normally do a good job in marketing the seed. Therefore, the main challenge in Morocco is mainly in relation to varietal development, release, licensing and ensuring the production and marketing of new seeds.

In the face of the clear yield, income and consumption benefits that old INRA-CG varieties provide Moroccan smallholders (Yigezu et al. 2018), these findings have important policy and institutional implications. These include the need to review and revise the variety release procedures to exploit the tremendous potential available from some highly productive varieties bred for specific agro-ecologies. They also include evaluation of incentives created by the royalty concession fees. INRA should consider producing and supplying 
start-up material (pre-basic seed) for further multiplication by seed companies. This might increase seed companies' interest for INRA-CG varieties. Finally, Morocco should develop effective strategies for enhancing the supply of certified seed through creation of a conducive environment for development of the commercial seed sector. This includes giving the seed subsidies directly to the farmers instead of to the seed companies - thereby creating a demand-driven seed system.

Acknowledgements Funding for this research was obtained from the CGIAR Research Program on Wheat - CRP-WHEAT (Agreement No. 200077).

Declarations We declare that there are no actual or potential conflicts of interest on the publication of this manuscript.

Open Access This article is licensed under a Creative Commons Attribution 4.0 International License, which permits use, sharing, adaptation, distribution and reproduction in any medium or format, as long as you give appropriate credit to the original author(s) and the source, provide a link to the Creative Commons licence, and indicate if changes were made. The images or other third party material in this article are included in the article's Creative Commons licence, unless indicated otherwise in a credit line to the material. If material is not included in the article's Creative Commons licence and your intended use is not permitted by statutory regulation or exceeds the permitted use, you will need to obtain permission directly from the copyright holder. To view a copy of this licence, visit http://creativecommons.org/licenses/by/4.0/.

\section{References}

Adato, M., \& Meinzen-Dick, R. (2007). Agricultural research, livelihoods, and poverty: Studies of economic and social impacts in six countries. Johns Hopkins University Press.

Alary, V., Yigezu, Y. A., \& Bassi, F. (2020). Participatory farmersweighted selection (PWS) indices to raise adoption of durum cultivars? Crop Breeding, Genetics and Genomics., 2(3), e200014. https://doi.org/10.20900/cbgg20200014.

Almekinders, C. J. M., Beumer, K., Hauser, M., Misiko, M., Gatto, M., Nkurumwa, A. O., \& Erenstein, O. (2019). Understanding the relations between farmers' seed demand and research methods: The challenge to do better. Outlook on agriculture. Vol., 48(1), 16-21.

Amankwah, A., Quagrainie, K. K., \& Preckel, P. V. (2016). Demand for improved fish feed in the presence of a subsidy: A double-hurdle application in Kenya. Agricultural Economics, 47, 633-643.

Asfaw, S., Shiferaw, B., Simtowe, F., \& Haile, M. (2011). Agricultural technology adoption, seed access constraints and commercialization in Ethiopia. Journal of Development and Agricultural Economics, 3(9), 436- 477.

Audi, P. O., Nagarajan, L., \& Jones, R. (2008). Seed interventions and cultivar diversity in pigeonpea. A farmer based assessment in eastern Kenya. Journal of New Seeds, 9(2), 111-127.

Bailey-Serres, J., Parker J.E., Ainsworth, E.A., Oldroyd, G.E.D., Schroeder, J.I. 2019. Genetic strategies for improving crop yields. Nature. 575(7781):109-118. https://doi.org/10.1038/s41586-019$1679-0$
Bishaw, Z., Y.A. Yigezu, A. Niane, R Telleria, D. Najjar (eds). (2019). Political economy of the wheat sector in Morocco: Seed systems, varietal adoption, and impacts. Cairo, 20.500.11766/9682.

Burke, W. J. (2009). Fitting and interpreting Cragg's Tobit alternative using Stata. Stata Journal, 9(4), 584-592.

Cragg, J. G. (1971). Some statistical models for limited dependent variables with application to the demand for durable goods. Econometrica, 39(5), 829-844.

David, S., Mukandala, L., \& Mafuru, J. (2002). Seed availability, an ignored factor in crop varietal adoption studies: A case study of beans in Tanzania. Journal of Sustainable Agriculture, 22(2), 5-20.

Diagne, A., \& Demont, M. (2007). Taking a new look at empirical models of adoption: Average treatment effect estimation of adoption rates and their determinants. Agricultural Economics, 37(2-3), 201210.

Dibba, L., Zeller, M., Diagne, A., \& Nielsen, T. (2015). How accessibility to seeds affects the potential adoption of an improved Rice variety: The case of the new Rice for Africa (NERICA) in the Gambia. Quarterly Journal of International Agriculture, 54(1), 33-58.

Evenson, R. E., \& Gollin, D. (2003). Assessing the impact of the green revolution, 1960 to 2000 . Science, 300, 758-762.

FAOStat. 2017. Online database. http://faostat3.fao.org/home/E. Accessed 4 Oct 2019.

Feder, G. (1980). Farm size, risk aversion and the adoption of new technology under uncertainty. Oxford Economic Papers, 32, 263-283.

Gisselquist, D., \& Van Der Meer, C. (2001). Regulations for seed and fertilizer markets: A good practice guide for policymakers. Rural development working paper 22817, World Bank, Washington, DC.

Hall, A., Rasheed Sulaiman, V., Clark, N., \& Yoganand, B. (2003). From measuring impact to learning institutional lessons: An innovation systems perspective on improving the management of international agricultural research. Agricultural Systems, vol., 78, 213 241.

Hassan, R. M., Mekuria, M., \& Mwangi, W. (2001). Maize breeding research in eastern and southern Africa: Current status and impacts of past investments made by the public and private sectors, 1966-97. Impact studies 23723, CIMMYT: International Maize and Wheat Improvement Center.

Hounkonnou, D., Kossou, D., Kuyper, T. W., Leeuwis, C., Nederlof, E. S., Röling, N., Sakyi-Dawson, O., Traoré, M., \& van Huis, A. (2012). An innovation systems approach to institutional change: Smallholder development inWest Africa. Agricultural Systems, vol., 108, 74-83.

INRA. (n.d.) Unpublished report. The accounting books of Institut National de la Recherche Agronomique (INRA), Morocco for the period 2002-2014.

Lahlou, O., Imani, Y., Slimani, I., Van Wart, J., \& Yang, H. (2016). Yield gap mapping as a support tool for risk management in agriculture, in: EGU General Assembly Conference Abstracts.

Lantican, M.A., H.J. Braun, T.S. Payne, R. Singh, K. Sonder, M.Baum, M. van Ginkel, \& O. Erenstein. (2016). Impacts of international wheat improvement research, 1994-2014. Technical Report. International Maize and Wheat Improvement Center (CIMMYT).

Louwaars, N. P., de Boef, W. S., \& Edeme, J. (2013). Integrated seed sector development in Africa: A basis for seed policy and law. Journal of Crop Improvement, 27(2), 186-214.

Munyi, P., \& De Jonge, B. (2015). Seed systems support in Kenya: Consideration for an integrated seed sector development approach. Journal of Sustainable Development, 8(2), 161-173.

Nagarajan, L., Audi, P., Jones, R., \& Smale, M. (2008). Seed provision and dry land crops in the semi-arid regions of eastern Kenya, IFPRI discussion paper n. 738 .

Nasserlhaq, N.A. A., \& Nachit, M. (2006). Amélioration génétique du blé tendre. Pages 59-95 in La Création Variétale à l'INRA: 
Méthodologie, Acquis et Perspectives. (F. Abbad Andaloussi et A. Chahbar, ed.). INRA, Rabat, Morocco.

Renkow, M., \& Byerlee, D. (2010). The impacts of CGIAR research: A review of recent evidence. Food Policy, 35(5), 391-402.

Sen, A. (1981). Ingredients of famine analysis: Availability and entitlements. The Quarterly Journal of Economics, 96(3), 433-464. https://doi.org/10.2307/1882681.

Setimela, P.S., Badu-Apraku, B., \& Mwangi, W. (2009). Variety testing and release approaches in DTMA project countries in sub-Saharan Africa. Harare, . https://www.researchgate.net/publication/ 282604655 Variety_Testing_and_Release_Approaches_in DTMA_Project_Countries_in_sub-Saharan_Africa. Accessed $1 \overline{5}$ Dec 2020.

Shiferaw, B., Kebede, T., Kassie, M., \& Fisher, M. (2015). Market imperfections, access to information and technology adoption in Uganda: Challenges of overcoming multiple constraints. Agricultural Economics, 46(4), 475-488.

Simtowe, F., Marenya, P., Amondo, E., Worku, M., Rahut, D. B., \& Erenstein, O. (2019). Heterogeneous seed access and information exposure: Implications for the adoption of drought-tolerant maize varieties in Uganda. Agricultural and Food Economics, 7(15), 1-23.

Smale, M., \& Heisey, P. W. (1994). Maize research in Malawi revisited: An emerging success story? Journal of International Development, 6(6), 689-706.

Smale, M., Cohen, M., \& Nagarajan, L. (2009). Local markets local varieties: Rising food prices and small farmers ' access to seed, IFPRI issue brief, N. 59.

Spielman, D. J., \& Smale, M. (2017). Policy options to accelerate variety change among smallholder farmers in South Asia and Africa south of the Sahara. IFPRI discussion paper 1666. Washington, D.C. http://ebrary.ifpri.org/cdm/ref/collection/ p15738coll2/id/131364

Spielman, D. J., Mekonnen, D. K., \& Alemu, D. (2012). Seed, fertilizer, and agricultural extension in Ethiopia. In P. A. Dorosh \& S. Rashid (Eds.), Food and agriculture in Ethiopia: Progress and policy challenges. International Food Policy Research Institute. University of Pennsylvania Press.

Thirtle, C., Lin, L., \& Piesse, J. (2003). The impact of research-led agricultural productivity growth on poverty reduction in Africa, Asia and Latin America. World Development, 31(12), 1959-1975.

Tripp, R. (1997). Between states and markets: Innovation for small-scale seed provision. In D.D. Pohrback, Z. Bishaw, and A.J.G. Van Gastel (eds.). Alternative strategies for smallholder seed supply. Proceedings of an international conference on options of strengthening national and regional seed systems in Africa, 10-14 March 1997, Harare, Zimbabwe. International Center for Research in the semi-arid tropics (ICRISAT), Andhra Pradesh, . pp: 195-220.

Tripp, R., \& Louwaars, N. (1997). Seed regulation: Choices on the road to reform. Food Policy, 22(5), 433-446.

Tripp, R., \& Rohrbach, D. (2001). Policies for African seed enterprise development. Food Policy, 26, 147-161.
Turner, M. R., \& Bishaw, Z. 2016). A review of variety release procedures and related issues: With recommendations for good practice. International Center for Agricultural Research in the dry areas (ICARDA), working no. 31. https://apps.icarda.org/wsInternet/ wsInternet.asmx/DownloadFileToLocal?filePath=Working_Paper Series/working-paper-31.pdf\&fileName=working-paper-31.pdf. Accessed 3 Oct 2019.

Walker, T., \& Alwang, J. (eds.). (2015). Crop improvement, adoption, and impact of improved varieties in food crops in sub-Saharan Africa. CABI International.

WB. (2006). Enhancing agricultural innovation: How to go beyond the strengthening of research systems. World Bank.

Yigezu, Y.A., Boughlala, M., El-Shater, T., Najjar, D., Bentaibi, A. 2019. Analysis of the adoption, impacts, and seed demand of improved varieties. In: Bishaw, Z., Y.A. Yigezu, A. Niane, R Telleria, D. Najjar (eds). Political economy of the wheat sector in Morocco: Seed systems, varietal adoption, and impacts. International Center for Agricultural Research in the Dry Areas, Beirut, Lebanon. 300 pp. http://doi.org/20.500.11766/8505.

Yigezu, Y. A., Alwang, J., Rahman, M. W., Mollah, M. B. R., El-Shater, T., Aw-Hassan, A., \& Sarker, A. (2018). Is DNA fingerprinting the gold standard for estimation of adoption and impacts of improved lentil varieties? Food Policy, 83, 48-59. https://doi.org/10.1016/j. foodpol.2018.11.004.

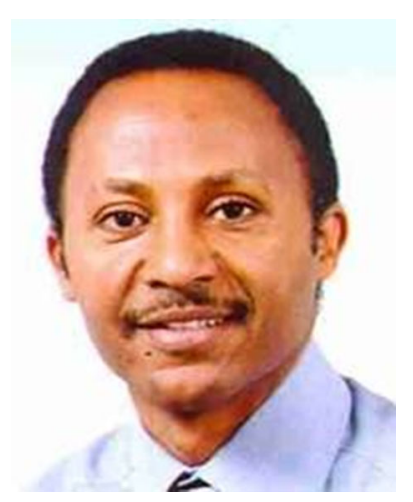

Yigezu A. Yigezu is an agricultural economist with focus on international development. He has research interest and experience in various areas of agricultural development including policy analysis, production economics, bioeconomic modeling of production systems and technology adoption, out-scaling, and impact assessment. Yigezu earned a $\mathrm{PhD}$ in agricultural economics from Purdue University in the United States in 2009. Ever since, he worked with the International Center for Agricultural Research in the Dry Areas (ICARDA) holding progressive positions. Prior to his graduate studies, Yigezu also worked for 14 years with governmental and non-governmental organizations. Yigezu has supported research projects in over 16 countries in Africa, Asia, and North America and published 28 peer reviewed journal articles, 5 book chapters, 6 working papers in numbered series, over 40 conference proceedings, and over 50 project reports and has co-edited a book. 


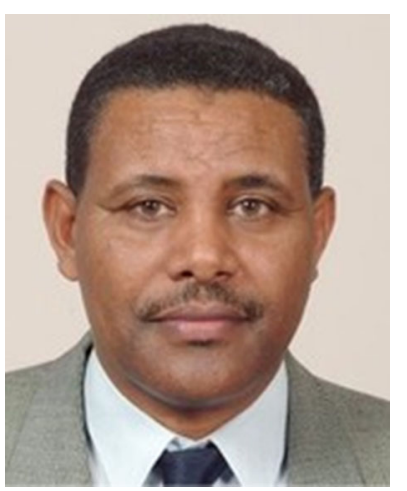

Zewdie Bishaw obtained his $\mathrm{PhD}$ in Production Ecology and Sustainable Conservation from Wageningen University, the Netherlands. Currently he is the Head of Seed Section \& International Nurseries, Ethiopia Country Manager and Interim Coordinator of TAAT Wheat Compact at ICARDA. He has broad knowledge and long experience in management, research and development in agriculture and seed sector in Africa and Asia. Dr. Bishaw has an extensive experience in mobilizing resources and implementing bilateral and multilateral projects at national and/or regional levels. He has also extensive firsthand working experience with government officials, NARS leaders, seed program leaders, public and private seed companies, farmers' groups, NGOs, regional/ international advanced research centers, and international agricultural and seed sector development organizations. Dr. Bishaw has authored and co-authored about 140 scientific and technical publications on broad range of topics including 34 journal articles, 8 book chapters, 22 proceeding papers (22) and 4 books/proceedings.

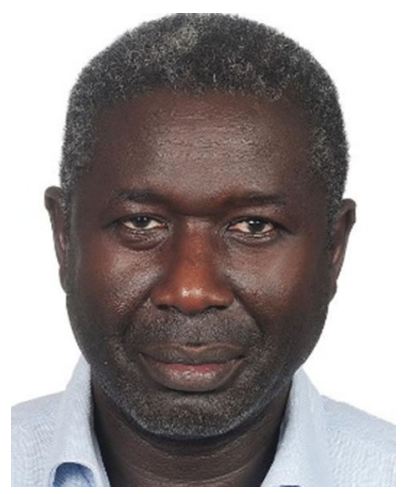

Abdoul Aziz Niane is a seed technologist and rangeland ecologist with more than 30 years of experience in crop management and post-harvest seed operations. Since joining ICARDA in 1987 , he has worked on seed production and post-harvest operations with extensive regional activities, including training and technical support on national seed system diversification. He has led the operation and diversification of seed delivery systems and implemented rangeland ecosystem monitoring and rehabilitation efforts. Dr. Niane has authored more than 20 peerreviewed publications. His research interests include basic and applied research on seed science and technology. He received his Ph.D. in rangeland ecology from Wageningen University in the Netherlands, and a M.Sc. in plant protection from Cukuruva University in Turkey.

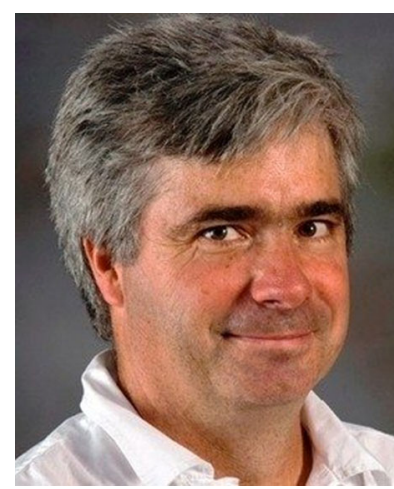

Jeffrey Alwang Since 1989, Dr. Alwang has worked as Assistant, Associate and Full Professor, in the Department of Agricultural Economics, Virginia Tech. He has been teaching: Rural and Regional Policy; Dynamic Economic Analysis; International Agricultural Development and Trade. Research focused on poverty and vulnerability, agricultural and food price policy, policies for environmental preservation. He has also worked as a consultant for several national and international organizations. He has raised over $\$ 11$ million in grants and carried several projects in many countries in Africa, Asia, North America and Latin America. Dr. Alwang earned a PhD from Cornell University in 1989 and has published over 90 journal articles, several book chapters and co-edited many books.

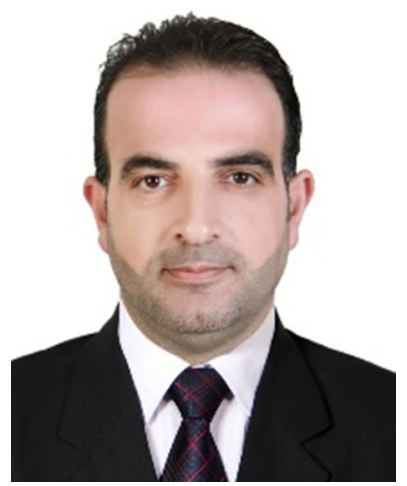

Tamer El-Shater is an agricultural economist familiar with issues related to farm household decision making, risk analysis, land use and tenure, different forms of resource degradations, markets, institutions, policies, climate change and the importance of technologies and factors that affect their adoption. He has research interest and experience in assessing poverty, natural resources degradation, and typologies of rural households in the region using participatory and community approaches. Since 2008, he worked as Senior Research Assistant and Research Associate with the International Center for Agricultural Research in the Dry Areas (ICARDA). Tamer earned his Ph.D. degree in agricultural economics from Damascus University in 2012. Tamer has published 12 peer reviewed journal articles, 2 book chapters, 5 working papers in numbered series, and over 10 project reports. 


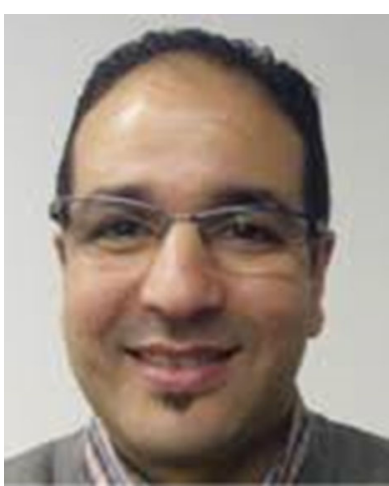

Mohamed Boughlala Since 2019, Mr. Boughlala has been the director of the Settat Agricultural Research Center of the National Institute for Agricultural Research in Morocco (INRA) of Morocco. Between 1995 and 2018, Dr. Boughlala worked as an agricultural Economist with INRA where he led several bilateral and multilateral projects. Dr. Boughlala has an MSC in Agricultural Economics from Université Hassan II. He has more than 50 publications in journals, working papers and book chapters.

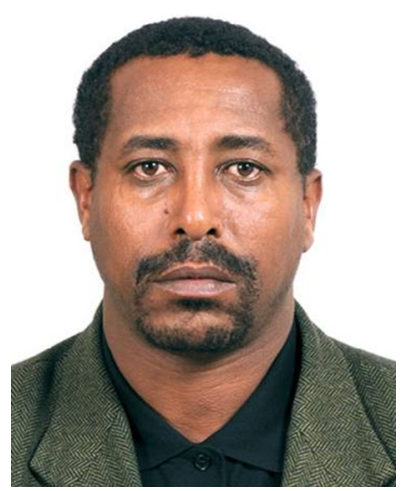

Wuletaw Tadesse leads the spring bread wheat breeding program at ICARDA. Before joining the Center in 2010 he worked at CIMMYT as a postdoctoral wheat breeder and in the Ethiopian Agricultural Research Institute as a crop breeder. Dr. Tadesse's research focuses on the development of widely adapted and high yielding wheat genotypes with resistance to major biotic (diseases and insects) and abiotic (drought and heat) stresses in sub-Saharan Africa and the Central and West Asia and North Africa (CWANA) region. In the past five years, in collaboration with national partners, his program released more than 60 ICARDA wheat varieties in sub-Saharan Africa and CWANA. Dr. Tadesse has published more than 30 articles in ISI journals, and supervised 15 master's and Ph.D. students. He received his Ph.D. in plant breeding and genetics from the Technical University of Munich, Germany, and his master's degree from Addis Ababa University in Ethiopia.

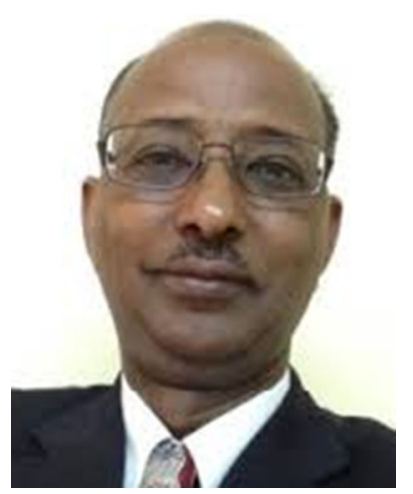

Aden Aw-Hassan is an agricultural Economist who, since January 2018, has been working as a part-time consultant with the International Center for Agricultural Research in the Dry Areas (ICARDA). Since 2006, Dr. Aw-Hassan was the director of the Social, Economic, and Polity Research program at ICARDA. Between 1992 and 2005, he had held different position (postdoc, scientist and senior scientist) with ICARDA. Dr. AwHassan earned a PhD degree in Agricultural Economics from Oklahoma State University in 1992. He has more than 100 publications through different media including peer reviewed articles, book chapters, working papers and books.

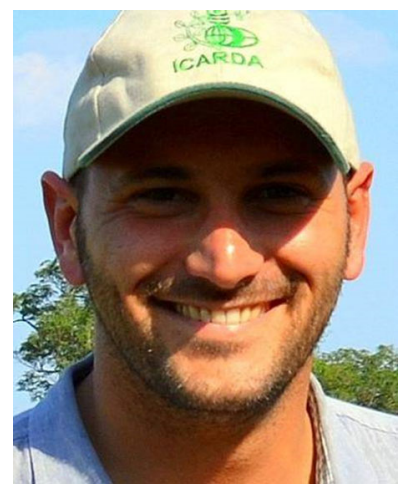

Filippo M. Bassi is a senior scientist leading ICARDA's Durum Wheat Breeding Program, which aims to deliver superior varieties with increased yields against a backdrop of rapid climate change. $\mathrm{He}$ also works in Ethiopia, India, Senegal, Mauritania, Lebanon, Algeria, Tunisia, and several other countries, to improve local scientists' capacity to innovate. He was the recipient of the 2017 OLAM Prize for Innovation in Food Security for the release of heat-tolerant durum wheat varieties in the Senegal River Basin, and also won the Beachell-Borlaug Scholarship. He is a member of the Wheat Initiative's Scientific Steering Committee, which oversees the Expert Working Group in Durum Wheat. Dr. Bassi holds a Ph.D. in plant breeding and genetics from North Dakota State University in the United States, and a master's degree in plant biotechnology from the University of Reggio Emilia in Italy and the University of Adelaide in Australia. 


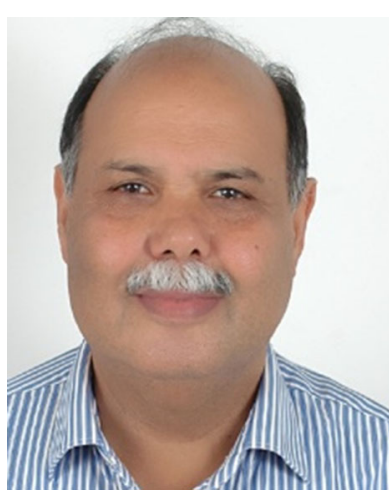

Ahmed Amri PhD in Genetics and Crop Sciences, Kansas State University, USA, worked as cereal breeder (1980-1999) at INRAMorocco and contributed to release of 17 barley varieties and 10 Hessian fly resistant wheat varieties (INRA). He joined ICARDA as regional coordinator of GEF-funded project of West Asia Dryland agrobiodiversity (1999-2005) and contributed to development of holistic approach for in-situ/on-farm conservation of landraces and wild relatives of cereals, legumes and fruit trees. He has assumed coordination of ICARDA offices in Jordan, Iran, Egypt and Morocco and head of genetic resources (2008-2019) and led the relocation of genetic resources core activities to Lebanon and Morocco including establishment of operational genebanks and intensive regeneration and characterization. He has published 178 papers and co-advised $27 \mathrm{MSc}$. and PhD students. His efforts were acknowledged by several countries and institutions and through the Gregor Mendel Prize by German Government and the Gatekeepers award provided by the Crop Trust.

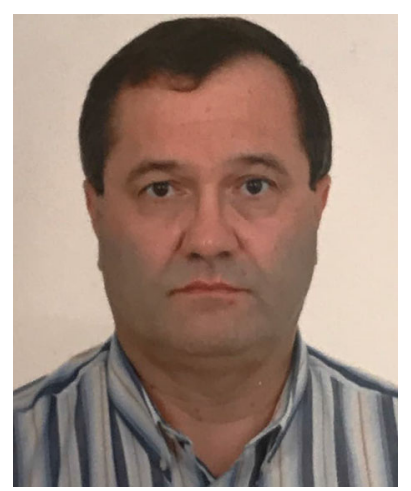

Michael Baum is director of ICARDA's Biodiversity and Crop Improvement Program, which comprises 30 scientists and 67 technical staff whose work ranges from crop breeding and cereal and legume pathology to virology and pollinators. Since joining ICARDA in 1992 as a biotechnologist, he has overseen ICARDA's biodiversity and crop management work in a number of countries across the Middle East and North Africa. Dr. Baum has been instrumental in establishing important partnerships between ICARDA's breeding program and several global research institutes. He has attracted over $\$ 10$ million in funding to build ICARDA's biotechnology program and strengthened biotech research across the dry areas. Dr. Baum has published over 110 peerreviewed journal articles, 30 book chapters, and 40 conference papers. Dr. Baum holds a Ph.D. in plant breeding and cytogenetics from the University of Göttingen in Germany. 